Hana Librová. Vèrní a rozumní: kapitoly o ekologické zpozdilosti. Brno: Masarykova univerzita 2016, 328 s.

\title{
Ondřej Čadek
}

Poslední knihou profesorky Hany Librové $\mathrm{z}$ oblasti sociologického výzkumu dobrovolně skromných rodin, ale i jedinců, se stala publikace $\mathrm{s}$ názvem Věrni a rozumni. První kniha, Pestř́ a zeleni z roku 1994, zkoumá životní styl právě těch lidí, kteří se rozhodnou pro tzv. dobrovolně skromný život. Druhá kniha, Vlažni a váhavi z roku 2003, se po deseti letech vrací svým výzkumem $\mathrm{k}$ týmž rodinám, $\mathrm{s}$ ambicí odhalit případné změny v životních postojích a hodnotách respondentů. O další desetiletí později pak vzniká dosud poslední, třetí kniha, Vèrni a rozumní.

Domnívám se, že napsat recenzi na Věrné a rozumné nebude samo o sobě možné, aniž bychom se alespoň stručně nedotkli dvou předchozích knih. Ostatně i sama autorka tak činí, když ve Věrných a rozumných věnuje značnou část textu právě rekapitulaci předchozích výzkumů.

Ještě než přistoupíme ke shrnutí a následnému hodnocení díla Hany Librové, dovolil bych si zdůvodnit, proč jsem si pro filosoficky zaměřený časopis vybral právě dílo, které se zdá býti spíše sociologické.

Velká část sociologických prací prof. Librové se zaměřuje na zkoumání vztahu člověka a přírody, hledá motivy a důvody, jak si lidé ve vztahu vůči prŕírodě počínají. Autorka si je již na počátku vědoma nepř́iznivého stavu prostředí, ve kterém žijeme. Je si vědoma, že nepříznivé ekosystémové změny (vymírání druhů, proměna krajiny, neobvyklé výkyvy počasí), o kterých mluví ochránci přírody, mají hlavní příčinu v lidském jednání, přímo ovlivňujícím přírodní rovnováhu. Na začátku výzkumu tedy stojí předpoklad, že důvodem nepříznivých klimatických změn je náš životní styl. Jak Librová uvádí v Pestrých a zelených, v roce 1992 tehdejší ministr životního prostředí Josef Vavroušek vyjádřil podporu sociologickému výzkumu, který měl zjistit, jestli u nás žijí lidé, kteří se dobrovolně spokojí s nízkou hmotnou spotřebou, jak jejich život vypadá, a zda je možné uplatnit ho jako vzorec pro šíření ekologicky příznivého způsobu života. ${ }^{1}$

Librová však samotný výzkum a konkrétní způsob života vybraných respondentů prezentuje vždy až v druhé polovině svých knih. Všechna tři díla zabývající se ekologicky příznivým způsobem života věnují výraznou část textu bohatému přehledu vzorců chování, které lze u člověka spatřit, je-li konfrontován s informací o neblahém stavu přírodního prostředí. Navíc je zde prezentováno široké spektrum názorů nejrůznějších myslitelů, kteří chování jednotlivců a společnosti vysvětlují, ale také nabízejí konkrétní vodítka, jak snížit svůj negativní dopad na život. Librová tak zcela záměrně předkládá

1 Viz Hana Librová, Pestři a zelení: (kapitoly o dobrovolné skromnosti), Brno 1994, s. 95. Srov. Hana Librová, Vèrni a rozumni: $k a$ pitoly o ekologické zpozdilosti, Brno 2016, s. 161. 
různé motivy a hodnoty, na jejichž základě je možné založit život jednajícího.

Nicméně autorka je ve všech třech knihách věrná etice dobrovolné skromnosti, jakožto nejlepšímu způsobu vypořádáním se s neblahým stavem životního prostředí, o kterém přesvědčivě víme už několik desetiletí. Tato etika, jakkoliv je vznešená a ctnostná, se sama o sobě nejeví z hlediska situace dnešní doby dost efektivní na to, aby mohla nepříznivý stav obrátit v náš prospěch. Každopádně Librová svými výzkumy a knihami jistě pozitivně ovlivnila větší počet lidí, než se může na první pohled zdát. Její texty jsou velice čtivé a inspirativní i pro utváření jiného typu ekologické etiky. O takovou se pokouším v rámci disertační práce, zatímco zde se podíváme blíže právě na etiku dobrovolné skromnosti.

A nyní už k Pestrým a zeleným. Dobrovolná skromnost je centrálním bodem sociologického výzkumu a hlavním kritériem pro výběr respondentů. Od tzv. záměrné skromnosti se liší tím, že se ve svém jednání neváže na nějakou konkrétní ideologii, např. environmentalismus. Lidé, kteř́ žijí skromně na základě dobrovolnosti, tak činí kvůli alternativním hodnotám, jež sami zastávají. Neodpovídají společenským konvencím v tom smyslu, že nechtějí přistoupit na život založený v materiálním nabývání majetku, protože raději věnují svůj čas životu na venkově, svým rodinám, občanské angažovanosti v místě bydliště apod. Mají dobré sousedské vztahy a umějí si kdykoliv vzájemně pomoci. Naopak nemají rádi nakupování, uspěchaný způsob života a s ním související stres. Tyto dobrovolně skromné lze tedy podle Librové také označit za alternativ- ní, neboli pestré. Můžeme o nich říci, že žijí bohatý život skromnými prostředky. Dotazovaní často pracují v nepř́liš dobře placených zaměstnáních, ale dělají skutečně to, co je baví, v čem vidí smysl. I když sami přiznávají, že musí vyjít $\mathrm{s}$ málem, za žádnou cenu by své zaměstnání neměnili, pokud by měl být ohrožen jejich dosavadní způsob života. Ten, jak už bylo řečeno, nespočívá v nakupování věcí, které nejsou potřeba. Díky tomu jsou rodiny postupně schopné ušetřit mnohem více peněz, než je tomu u běžné části populace, kterou uspokojuje pocit pořídit si něco nového. Pestří často investují do rekonstrukce svých sídel. Neradi se stěhují a cestují, protože mají blízký vztah k místu svého bydliště. $\mathrm{V}$ devadesátých letech ještě nikdo z respondentů nevlastnil automobil a náročnější domácí spotřebiče. Ve vybavení každé domácnosti bychom např. našli jízdní kolo.

Ve druhé knize, Vlažni a váhaví, se Librová vrací ke svým respondentům s obavou, zda a do jaké míry podlehli atmosféře společnosti, která se pyšní neustálým ekonomickým růstem, a jejíž materiální podstata se chtě nechtě dotýká každého jejího člena. A skutečně, i ženy v domácnosti si najednou byly nuceny najít zaměstnání a některé rodiny si pořídily automobil, když začaly s podnikáním. Objevují se počítače, mobilní telefony a některé domácí spotřebiče. Ani pestří tedy nemohou zůstat "trčet v tekutých píscích" ${ }^{2}$ a odolat veškerým společenským tlakům. Více než pozitivní však zůstává skutečnost, že pestří jsou stále věrní svým hodnotám, životu založenému na dobrovolné skromnosti.

2 Viz H. Librová, Věrni a rozumni..., s. 271. 
Autorka u svých respondentů nachází touhu po luxusu, který je však ekologické povahy. Právě v něm vidí naději na zlepšení dosud nepříznivého stavu prostředí. Ekologický luxus předpokládá informace o následcích vlastního jednání a cit pro přírodu. Spočívá v radosti, zájmu o druhé lidi, zvířata, ve fyzické i duševní práci. Ekologický luxus je zde možné chápat jako altruistickou morálku. Zmenšuje neblahý vliv člověka na přírodu a tvoří protiváhu materiálnímu způsobu života. Pro etiku ekologického luxusu se zde nabízí imperativ: „Spěchej pomalu!"3 Nejedná se totiž o klid jogína, ale chytř̌e zvládnutý nepokoj Evropana.

Konečně můžeme přistoupit $\mathrm{k}$ V̌rrným a rozumným. Librová začíná knihu osobním vyjádřením o stavu současné veřejnosti, která nejeví zájem o přírodu. Situace je bohužel taková, že většina lidí hledí především na své zájmy, které jsou stále založeny na materiálních statcích a jakémsi pohodlí, na neochotě udělat něco navíc, pro celek. Jeden $\mathrm{z}$ důvodů tohoto stavu může být dezorientace ve světě rozporuplných informací. Problém životního prostředí se tak stává obtížně uchopitelným, lidé o něj nejeví zájem, je nepopulární. Librová se domnívá, že se tak děje i z důvodu jakéhosi vytržení člověka z přírody. Celé dny totiž trávíme v kancelářích, budovách, ve městech, nejsme s přírodou ve styku, a tak není divu, že o ni nejevíme zájem. Autorka je tímto stavem hluboce znepokojena a cituje v téhle souvislosti Václava Bělohradského,

3 Hana Librová, Vlažni a váhavi: (kapitoly o ekologickém luxusu), Brno: Doplněk 2003, s. 136. který už před šestnácti lety řekl, že „být na straně motýlů je kategorický imperativ naší doby."

Z hlediska etiky je kniha obohacena několika výkladovými klíči, neboli teoretickými koncepty, které vysvětlují motiv jednajících, našich respondentů.

Klíč univerzální je založen na věrnosti vůči ustupující přírodě. Vychází z představy, že lidé nejsou dokonalí, zatímco př́roda je dobrá a krásná. Proto je třeba přistupovat $\mathrm{k}$ ní nejen se soucitem, ale i s odpovědností.

Klíč ontologický pracuje s typologií lidských činností dle rozdělení Hannah Arendtové. Člověk př́rodu a své okolí bud' přetváří/zhotovuje (homo faber), nebo naopak udržuje, pečuje o druhé apod. (homo curans). Třetí typ činného života spočívá v jednání, myšleno spíše v politickém a organizačním smyslu (homo agens). Z hlediska vlivu na životní prostředí má pozitivnější dopad práce udržující (péče o to, co jest) před prací zhotovující (přetváření přírody).

Klíč psychologický popisuje, jak se jednotlivci staví k environmentálním hrozbám, resp. jak reagují na nepříznivé informace o stavu prostředí. Jelikož někteří nechtějí uznat svůj díl viny na situaci, uchylují se k obranným strategiím. Tzv. nezralé strategie zpochybňují či oslabují význam nepříznivých informací. Naopak zralé strategie informace přijímají a vedou ke změně chování. Psychologové radí ekologům, že není příliš vhodné strašit veřejnost nepříznivými informacemi, protože je pro většinu lidí pohodlnější odmítnout spoluvinu a uchýlit se k nezralým H. Librová, Věrni a rozumní.., s. 20. 
strategiím. S tím by jistě nesouhlasil Hans Jonas ani Thomas Hobbes. Oba totiž chápou ohrožení a strach o život jako dobrý důvod $\mathrm{k}$ vytvoření podmínek garantujících sebezáchovu.

Klíč motivační je zde definován třemi různými typy motivace ekologicky př́znivého chování. Teleologická motivace předpokládá, že lze veškeré hrozby odvrátit naplněním stanovených cílů. Např. se sám sebe zeptám, co vše mohu udělat, abych zmenšil svoji ekologickou stopu? Naopak deontologická motivace na cíle nehledí. Zdá se, že postrádá racionalitu, nebot' se odvolává spíše na zvyky, tradice. Říká nám, že př́roda musí být zachována v celé své kráse, protože tomu tak bylo vždy, a není tedy moudré ji př́liš přetvářet. Mluvíme o environmentálním konzervatismu, který zastává Roger Scruton. Pravděpodobně i duchovní otec konzervatismu Edmund Burke by dnes řekl, že musíme své chování změnit, aby byla př́íroda zachována. Třetím přístupem $\mathrm{v}$ tomto motivačním klíči je etika ctností. Zde se člověk za každou cenu snaží žít v souladu se svými hodnotami, a to jak ve vztahu $\mathrm{k}$ druhým lidem, tak $\mathrm{k}$ př́rodě jako takové. Tento životní způsob nemá konkrétní očekávání následků svého jednání, zahrnuje vlastně postoj záměrné i dobrovolné skromnosti.

Klíč teologický vysvětluje v duchu Starého zákona roli člověka ve světě. Jeho postoj může být bud' panský, v roli správce. Člověk je zde vnímán jako ten, kdo má stvořený svět spravovat. Nebo naopak je role člověka pastýřská, a to ve smyslu, že má být ochráncem slabších. Každopádně jak v roli správcovské, tak $\mathrm{v}$ roli pastýřské může člověk ekologickým škodám předcházet, uvědomí-li si, že i on je součástí stvoření.

Další část knihy věnuje Librová environmentálnímu žalu a tzv. zelené únavě. Jedná se o výčet nejrůznějších př́íladů a pozorování zaměřené na ubývání př́írodní rovnováhy. Nejvíce tím trpí právě ti, kteří se s těmito problémy konfrontují nejčastěji - ochránci př́rody, vědci, ale i běžní lidé, které lze označit za věrné. Velká část z nich už rezignovala na boj s větrnými mlýny, když se dostavil pocit frustrace z neúspěchu. Mnoho autorů se shoduje na tom, že ekologická krize je krizí kultury. Kvůli tomu hledají někteří útočiště v pěstování komunit, umění či řemeslných prací. Jakkoliv jsou to činnosti šlechetné, nakolik je to z hlediska ochrany přírody účinné?

Zcela jiné povahy jsou ti, které Librová nazývá rozumnými ekopragmatiky. Ti rozhodně environmentálnímu žalu nepropadají. Sdílejí sice názor, že planeta je nevratně poznamenaná, ale nevidí v tom zásadní problém. Je třeba pracovat s tím, co máme a co víme. Mají velice kladný vztah k technice, vidí v ní naději. Jsou zastánci utváření nových ekosystémů a šlechtění nové přírody člověkem, proto je můžeme označit za reprezentanty typu homo faber. Země má nadále sloužit člověku, ten jí dominuje od průmyslové revoluce. Ekopragmatici jsou zastánci antropocentrismu v nejsilnějším smyslu, protože jejich pohled znemožňuje chápat př́rodu jako samostatnou hodnotu. Autorka je vůči nim kritická právě kvůli představě, že základní podmínky života mají sloužit pouze jedinému druhu, lidem. Od kritiky antropocentrismu se Librová pouští do kritiky pojmu životního prostředí. 
Vadí jí právě význam onoho sousloví, nebot’ se za těmi slovy údajně skrývá to, že jde o životní prostředí člověka. Ne každý však pojem životní prostředí vnímá antropocentricky. Vždyt si za něj lze dosadit i podmínky života na Zemi obecně. Tato kritika je poněkud problematická, nebơ’ za životní prostředí si může každý dosadit něco jiného, jedná se spíše o problém filosofie jazyka.

Další část se vrací k věrným ochráncům př́rody. Mezi ně řadí i environmentálně smýšlejícího papeže Františka, který si všímá toho, že lidské i př́írodní prostředí upadají současně. Proto vyzývá k odhalení a vyřešení příčin tohoto úpadku. Pojem ekologa jako člověka pečujícího (homo curans) se mění v jednajícího (homo agens). To se děje s vidinou lepší efektivity svého úsilí, které často končí aktivismem (šumavská blokáda, Klimakemp).

Poslední teoretickou část knihy věnuje Librová pojmu protipř́írodní subkultury. Do té řadí odpůrce přírody, tzv. antinaturalisty. Ti totiž „chápou odcizení přírodě jako kladný rys lidství, jako základ kultury a civilizace. ${ }^{\text {5 }}$ Často mezi ně patří urbanisté a architekti, lidé zabývající se přestavbou přírodního prostředí v lidský prospěch. Někteří antinaturalisté dokládají své přesvědčení existencí evolučního zla ve světě. Oprávněně se ptají, proč příroda stvořila svět tak krutý, že život jednoho druhu závisí na zničení druhu jiného? Tato kapitola upozorňuje na antagonismus dobra a zla $\mathrm{v}$ prrírodě. Na pohled se z pohodlí našich domů může zdát, že vše je v rovnováze, zatímco ve skutečnosti na naší zahradě probíhá mezi drobnými

H. Librová, Věrni a rozumní.., s. 129. živočichy nelítostný boj o přežití. Záměrně je zde problém vyhrocen a čtenář je tak nucen položit si základní otázku: Je příroda dobrá, nebo zlá?

Ve filosoficky nejzajímavější části knihy se Librová vrací k sociologii, aby provedla průzkum „pestrých“ po 23 letech, v době, kdy je ještě mnohem snazší podlehnout tlaku doby. Téměř všichni bydleli na stejných místech, dospělé děti už měly své vlastní domácnosti. Terminologií Hannah Arendtové, pestří byli stále věrni ve svých profesích, ale i svým zájmům, činnostem v duchu homo curans. V důsledku osamostatnění svých dětí zbývalo mnohem více času nejen na zahradničení, ale i ostatní zájmy ve formě iniciování obecních akcí. Díky obecnému růstu mezd a věrnosti dobrovolně skromnému způsobu života s potěšením přiznávají, že prožívají blahobyt. Ten je však stále ekologické povahy. Zajímavé bylo sledovat spíše děti pestrých, resp. jak se na nich projevila alternativní výchova, mnohdy spočívající v domácím vyučování a skromném dětství. Děti byly vždy vedeny $\mathrm{k}$ samostatnosti a odpovědnosti. Možná proto, k překvapení autorky, v pubertě a dospělosti proti životnímu stylu svých rodičů nic nenamítaly. Během výzkumu vystupovaly podobně jako jejich rodiče, ačkoliv prý první dvě knihy nikdy nečetly. Změna byla však patrná v jejich vztahu k profesní realizaci, na které jim záleželo mnohem více. Nevadí jim život ve městech. Podobně dávají přednost humanitnímu vzdělání a pečujícím profesím (homo curans) bez fixace na kariérní úspěch. Odolnost vưči reklamě, odpor k nakupování zbytečností, to vše jako v případě jejich rodičů, bez nějaké ideologičnosti. 
Kde se bere tento ekologicky citlivý př́istup? Patrně je to důsledek poměrně liberální výchovy, nostalgického vzpomínání na dětství a nejspíš i odpovídajícího vzdělání. Jak pestří, tak jejich děti, chovají zálibu v ekologickém luxusu a zároveň mají skepsi vưči materiálním hodnotám. Vědomě či nevědomě je zde užíván Kohákův princip výběrové náročnosti, který se v případě nakupování odráží ve výběru těch šetrnějších alternativ.

Na závěr bych si dovolil stručně shrnout dojmy ze čtení kapitol o dobrovolné skromnosti, za které lze považovat zmíněné tři knihy H. Librové. Působily na mě totiž dvojím dojmem. V první řadě jako důkaz o zárodku šetrného životního stylu v českých domácnostech, který působil věrohodně a především inspirativně. Mezi řádky bylo možné sledovat, že o výdobytky ekologického luxusu a alternativních hodnot je stále vyšší zájem. Automobil přestává býti statusovým symbolem, především ve městech. Lidé se začínají více zajímat o udržitelnější způsob života a šetrné chování se v některých kruzích stává novým pojetím prestiže. Na druhou stranu ani sama autorka svůj environmentální žal nezatajila a nebála se podat nepříznivý obraz současné situace. Skutečnost je bohužel taková, že s neustále se zvětšujícím počtem populace na Zemi a obecně protipřírodně orientovanou kulturou se ekologickou krizi nedaří překonat. Dobrovolná, ale i záměrná skromnost je hrdinský pokus o ekologickou etiku, avšak pokud nebude podporována politikou, zůstane jen výsadou hrstky odvážných a v boji s větrnými mlýny nebude zápasit věčně. Přesto bych knihu doporučil přečíst všem, kteří chtějí žít bohatě, aby pochopili, že je to možné i skromnými prostředky. Etika dobrovolné skromnosti má v dnešním světě jen pramalou naději, aby se stala obecným zákonem. Může však posloužit jako vodítko těm, kteří chtějí žít v souladu se svými propřírodními hodnotami a pohybovat se na Zemi lehce.

\section{Mgr. Ondřej Čadek}

Katedra filozofie, Filozofická fakulta, Masarykova univerzita

Arna Nováka 1, 60200 Brno, Česká republika

461993@mail.muni.cz 
